\title{
Comparative properties of bagasse, canola and hemp particle boards
}

\author{
Neda Nikvash • Redelf Kraft • Alireza Kharazipour • \\ Markus Euring
}

Received: 2 March 2010 / Published online: 21 July 2010

(C) The Author(s) 2010. This article is published with open access at Springerlink.com

\begin{abstract}
Residues of Bagasse (Saccharum officinarum L.), canola (Brassica napus L.) and hemp (Cannabis sativa $\mathrm{L}$.) as well as industrial wood chips in various proportions from $0-100 \%$ were used as raw materials for the main component of the middle layer in urea formaldehyde bonded particle boards.

The results reveal that most of the investigated mechanical-technological properties of the boards achieved the requirements of EN 312-2 (2003). Only increasing the percentage of canola chips usage in the middle layer to more than $30 \%$ negatively affect the internal bond (IB) properties. Comparing the water absorption (WA) and thickness swelling (TS) values, the boards containing up to $50 \%$ bagasse and hemp reach similar values to the ones of the reference boards, while increasing the amount of canola leads to more and more disadvantageous WA and TS.

In summary, the results reveal that agri-fibers can be used for making composite panels conforming to the standards (EN 312-2 2003). One possible application for these panels could be the production of furniture.
\end{abstract}

\section{Einsatz von Ernterückständen von Bagasse, Rapsstroh und Hanfschäben bei der Herstellung von dreischichtigen Spanplatten}

This article is dedicated to Gerd Wegener on the occasion of his retirement as professor at the Technische Universität München.

N. Nikvash $\cdot$ R. Kraft · A. Kharazipour $(\bowtie) \cdot$ M. Euring Faculty of Forest Science and Forest Ecology, Buesgen-Institute, Department of Molecular Wood Biotechnology and Technical Mycology, Georg-August-University of Goettingen, Büsgenweg 2, 37077 Göttingen, Germany

e-mail: akharaz@gwdg.de
Zusammenfassung Ernterückstände der Einjahrespflanzen Bagasse (Saccharum officinarum L.), Raps (Brassica napus L.), und Hanf (Cannabis sativa L.) wurden in Anteilen von 0-100 \% zur Substitution von industrieüblichen Holzspänen in der Mittelschicht von Harnstoffformaldehydharz gebundenen Spanplatten verwendet.

Die Ergebnisse zeigen, dass nahezu alle mechanischtechnologischen Eigenschaften der Spanplatten die Anforderungen der EN 312-2 (2003) erfüllen. Lediglich bei Rapsanteilen über $30 \%$ wurde die von der Norm geforderte Querzugfestigkeit von 0,35 N/mm² nicht erreicht. Bei einem Vergleich der Ergebnisse der Dickenquellung und Wasseraufnahme zeigt sich, dass zwischen Platten mit Bagasseund Hanfanteilen in der Mittelschicht von bis $50 \%$ und den Referenzplatten kaum Unterschiede bestehen, während Platten mit zunehmenden Rapsanteilen hier immer deutlicher abfallen.

Zusammenfassend zeigen die Untersuchungen, dass sich Ernterückstände von Einjahrespflanzen zur Herstellung von normgerechten Spanplatten (EN 312-2 2003) eignen. Eine mögliche Verwendung dieser Spanplatten wäre der Einsatz in der Möbelindustrie

\section{Introduction}

In recent years the importance of wood and waste wood as a source of energy has increased due to soaring energy prices on the one hand. On the other hand, this situation has caused a sharp increase in the price of manufactured materials (EPF 2006).

Agricultural residues are an excellent alternative to using virgin wood chips for many reasons. At present some agricultural residues such as wheat and rice straws, sorghum stalks and some annual plants such as hemp and jute are used 
as raw materials for pulp and paper production (Rousu and Anttila 2002; Ashori 2006; Schöpper et al. 2009). Moreover numerous studies have been performed to introduce new lignocellulosic resources for paper and wood industries.

One of the most abundant natural resources is the byproduct of the sugar industry, the bagasse (Chen and Negulescu 2002). Bagasse (Saccharum officinarum L.) - a fibrous material-is one of the main by-products of sugarcane manufacturing plants which is obtained after the glucose syrup is leached out of the sugarcane. One developing application for bagasse fibers is in the manufacturing of material products, such as automobile interior trim parts (Mueller et al. 2001; Chen et al. 2003; Rowell and Keany 1991).

Another raw material of interest for the wood industry is canola. Canola (Brassica napus L.) is widely cultivated throughout the world and used as a major oilseed for vegetable oils and biodiesel production. In addition to oil production from the canola seed, the leaves of canola can be used as an animal feed (Banuelos et al. 2002). Thus, it can be concluded that at least 34 million tons of canola stalks are available annually which could be used in various products, including particle boards.

Actually the wood costs are generally rising with demand surpassing supply (Kharazipour 2005). In fact, the international wood-supply balance is now beginning to shift in favor of alternative non-wooden materials, including industrial hemp. Hemp is a plant called Cannabis sativa L. which is the most durable plant that has been used since pre-history for various applications. The hemp plant consists of long, strong fibers. The long fiber is hemp's best feature, even when ground up it is still two to three times stronger than comparative annual plants fibers (Osburn 1994). Another component of hemp is the sheaves. The sheaves amount to up to $60 \%$ of each hemp plant. In the past this material was only used as litter in animal stables. Especially in these studies the sheaves are used to produce particle boards (Karus 2005; Ohlhauser 2005; Cescutti and Müssig 2005; Schöpper et al. 2009). Today the goal of hemp farming is to use it for the production of wood composites (Karus 2005; Ohlhauser 2005).

In light of these changes, hemp sheaves may become increasingly competitive in price relative to wood, particu- larly since fast-growing tree species such as aspen, poplar and grand fir are the only alternatives to conventional wood sources in northern latitudes such as Europe (Lloyd 1996; Voß and Kharazipour 2010).

Combining wood with other materials from renewable resources creates new functional properties for wood composites (COST Action E20 2003).

This study is mainly focused on the research of properties with regard to wood chips with different percentages of hemp sheaves, bagasse and canola chips.

\section{Materials and methods}

\subsection{Board manufacturing}

Three-layer particle boards with a different percentage of wood chips and annual plant materials were manufactured in the pilot plant of Buesgen-Institute, Department of Molecular Wood-Biotechnology and Technical Mycology, Georg August University of Goettingen. The boards were made in different series from one year old bagasse material, agriculture residues canola chips and hemp sheaves. The chips and sheaves had been stored prior to the particle board manufacturing. They were hammer-milled to reach a size of ca. 6$\mathrm{mm}$, and were dried in a dry-oven to about 3-4\% moisture content (MC). The materials were finally mixed with different combinations of bagasse, canola and hemp and wood chips in the middle layer. The surface layer was of $100 \%$ wood chips. Both layers were glued with Urea Formaldehyde (UF) resin from BASF, Germany, formed into mats, and pressed into particle boards at $200{ }^{\circ} \mathrm{C}(70 \mathrm{~cm} \times 46.5 \mathrm{~cm}$ $\times 2 \mathrm{~cm}$ ) with target conditions listed in Table 1 . For each annual plant material (bagasse, canola and hemp) 15 particle boards were made.

\subsection{Preparation of materials}

The materials were industrial wood chips, ordered from Pfleiderer AG, Guetersloh, Germany. The annual plants bagasse (Saccharum officinarum) were received from Iran,
Table 1 Technical information for the manufacture of particle boards with bagasse, canola and hemp material in the middle layer (ML) and $100 \%$ wood chips in the surface layer (SL)

Tab. 1 Herstellungsparameter der Spanplatten aus Bagasse, Raps und Hanf in der Mittelschicht und $100 \%$ Holzspänen in der Deckschicht

\begin{tabular}{|c|c|c|c|c|c|c|c|}
\hline \multirow[t]{2}{*}{ Material } & \multicolumn{2}{|c|}{$\begin{array}{l}\text { UF-resin } \\
\text { content } \\
(\%)\end{array}$} & \multirow[t]{2}{*}{$\begin{array}{l}\text { Target } \\
\text { thickness } \\
(\mathrm{mm})\end{array}$} & \multirow[t]{2}{*}{$\begin{array}{l}\text { Target } \\
\text { density } \\
\left(\mathrm{g} / \mathrm{cm}^{3}\right)\end{array}$} & \multirow[t]{2}{*}{$\begin{array}{l}\text { Press time } \\
(\mathrm{s} / \mathrm{mm})\end{array}$} & \multirow[t]{2}{*}{$\begin{array}{l}\text { Press } \\
\text { temperature } \\
\left({ }^{\circ} \mathrm{C}\right)\end{array}$} & \multirow[t]{2}{*}{$\begin{array}{l}\text { Percentage of annual plant } \\
\text { in combination with wood } \\
\text { (middle layer) }(\%)\end{array}$} \\
\hline & $\overline{M L}$ & $\overline{\mathrm{SL}}$ & & & & & \\
\hline $\begin{array}{l}\text { 1. industrial } \\
\text { wood chips }\end{array}$ & 8 & 10 & 20 & 0.7 & 15 & 200 & $90,80,70,50,0$ \\
\hline 2. bagasse & 8 & 10 & 20 & 0.7 & 15 & 200 & $10,20,30,50,100$ \\
\hline 3. canola chips & 8 & 10 & 20 & 0.7 & 15 & 200 & $10,20,30,50,100$ \\
\hline 4. hemp sheaves & 8 & 10 & 20 & 0.7 & 15 & 200 & $10,20,30,50,100$ \\
\hline
\end{tabular}


hemp (Cannabis sativa) from Germany (Nordhanf $\mathrm{GmbH}$ ) and canola [Brassica Rapa (syn. Brassica campestris)] from an agriculture company from southwest Germany..

Three samples of each series of particle boards were produced. The fibers of the surface layer, in all series, consisted totally of industrial wood. The middle layers were a combination of 10, 20,30, 50 and 100 percent of bagasse, canola or hemp with industrial wood chips (see Table 1).

\subsection{Sample preparation and testing mechanical-technical properties of the particle boards}

The samples for various tests were prepared from the experimental boards according to the specifications shown in Table 2.

Bending MOE/MOR and internal bond (IB) strengths were tested with a Universal Testing Machine (ZWICK/ ROELL) according to EN-310 and EN-319 standards respectively.

Thickness swelling (TS) tests were done by means of the 24-hour water soaking procedure according to the EN 317 standard. Conditioned samples, square shape, having side lengths of $50 \mathrm{~mm} \pm 1 \mathrm{~mm}$ for the evaluation of thickness swelling (TS) were prepared according to EN 317 standard.

The measured properties were compared with the corresponding specifications listed in EN 312-2 (2003) for par-

Table 2 Test criteria, size and number of samples of the produced particle boards

Tab. 2 Testkriterien, Maße und Anzahl der Spanplattenproben

\begin{tabular}{lll}
\hline Test & $\begin{array}{l}\text { Sample size } \\
{[\mathrm{mm}]}\end{array}$ & $\begin{array}{l}\text { Number of samples } \\
\text { for each series }\end{array}$ \\
\hline Bending MOE/MOR & $50 \times 360 \times 20$ & $9 / 9$ \\
Internal Bond (IB) Strength & $50 \times 50 \times 20$ & 24 \\
Thickness Swelling (TS) & $50 \times 50 \times 20$ & 24 \\
Water absorbance & $50 \times 50 \times 20$ & 24 \\
\hline
\end{tabular}

ticle boards (category: particle boards for interior fitments including furniture EN 312-2 2003).

\section{Results and discussion}

\subsection{Bending MOE and MOR}

MOE and MOR as a function of sample strengths were measured. According to EN 312-2 (2003) the minimum requirement of modulus of rupture (known as bending strength) is $13 \mathrm{~N} / \mathrm{mm}^{2}$ (>13 to $20 \mathrm{~mm}$ thickness of particle boards). Figure 1 shows the bending properties of the bagasse, hemp, and canola particle boards. Various percentages of bagasse and hemp in the boards obtained higher values than those of boards containing canola. Based on these results, all bagasse, hemp and canola boards fulfill the minimum requirement of the EN standard. Figure 2 shows the modulus of elasticity of the particle boards. Boards containing hemp gained considerably better bending strength than the two other series (canola, bagasse). Based on the results, with a density of $700 \mathrm{~kg} / \mathrm{m}^{3}$, the values of boards are higher than those values which are required in EN 312-2 (2003).

\subsection{Internal bond strength (IB)}

The bar chart of the IB strength as a function of mechanical strengths is shown in Fig. 3. Similar to the MOE and MOR data, bagasse and hemp's IB strengths fulfilled the minimum requirement of European standards. In all combinations of bagasse with wood chips in the middle layer the requirements of EN 312-2 (2003) could be highly fulfilled.

The results of the hemp particle boards show the best IBs. They are nearly two times higher than the standard value. The case of this strong difference can be mentioned by the usage of hemp sheaves in the middle layer of the boards. In contrast to hemp sheaves, the use of more than $50 \%$ of canola material could not meet the standard value. The achieved value in canola $30 \%$ was $0.35 \mathrm{~N} / \mathrm{mm}^{2}$, which is the minimum value requirement in EN 312-2.
Fig. 1 Comparison of the bending strengths of particleboards, containing bagasse, hemp and canola, each in mixture with wood in the middle layer

Abb. 1 Vergleich der Biegefestigkeiten der Spanplatten jeweils mit Bagasse, Hanf und Raps in Mischung mit Holz in der Mittelschicht

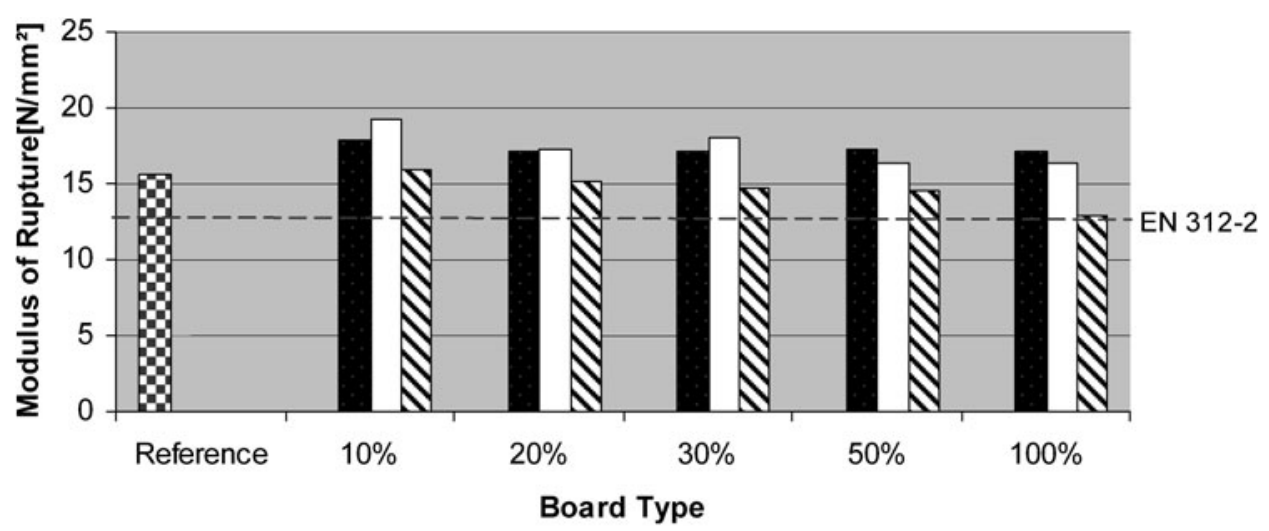

@ Reference $\square$ Bagasse $\square$ Hemp s Canola 
Fig. 2 Comparison of bending modulus of particle boards, containing bagasse, hemp and canola, each in mixture with wood in the middle layer Abb. 2 Vergleich des Elastizitätsmoduls der Spanplatten jeweils mit Bagasse, Hanf und Raps in Mischung mit Holz in der Mittelschicht

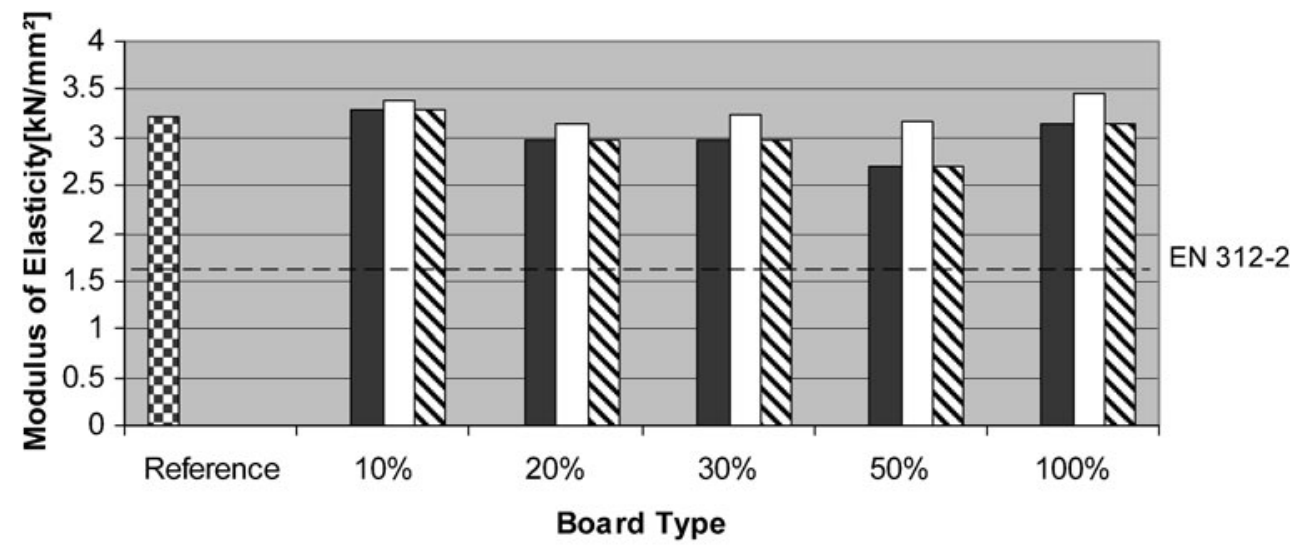

口 Reference $\square$ Bagasse $\square$ Hemp $\mathbf{\Xi}$ Canola

Fig. 3 Comparison of Internal Bond Strength of particle boards, containing bagasse, hemp and canola, each in mixture with wood in the middle layer

Abb. 3 Vergleich der Querzugfestigkeiten der Spanplatten jeweils mit Bagasse, Hanf und Raps in Mischung mit Holz in der Mittelschicht

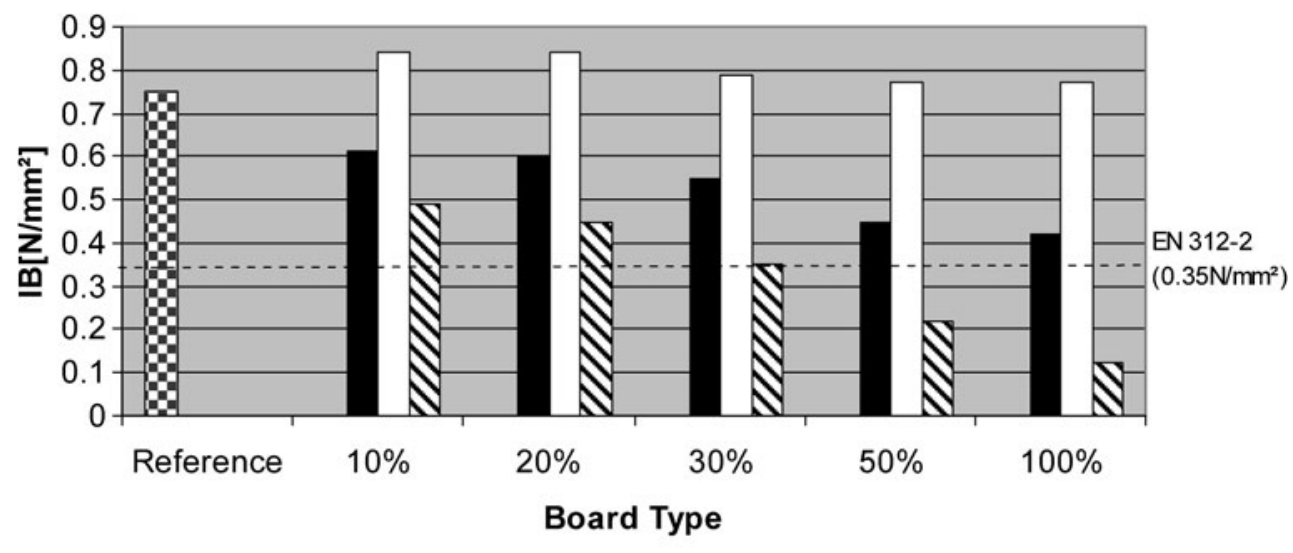

Reference $\mathbf{B}$ Bagasse $\square$ Hemp $\boldsymbol{\nabla}$ Canola

\subsection{Thickness Swelling}

The TS and water absorption (WA) data for all series are summarized in Figs. 4 and 5. The values for thickness swelling after immersion in water are shown in Fig. 4. In comparison to the reference, all values from $10 \%$ to $30 \%$ for the series of hemp and bagasse are very similar (Fig. 4). Increasing usage of canola in the boards' middle layer shows more and more negative effects.

The mean WA for hemp series, except in the mixture of $100 \%$, was less than reference value. The WA average for bagasse from $10 \%$ to $30 \%$ in mixture was lower than the value of the reference. The particle boards with a middle layer mixture of $50 \%$ and $100 \%$ bagasse were higher than the reference value. All mixtures of canola show higher WA in comparison to all other boards (Fig. 5).

\section{Conclusion}

These studies show that particle boards with a middle layer of annual plants such as bagasse, hemp and canola in dif-

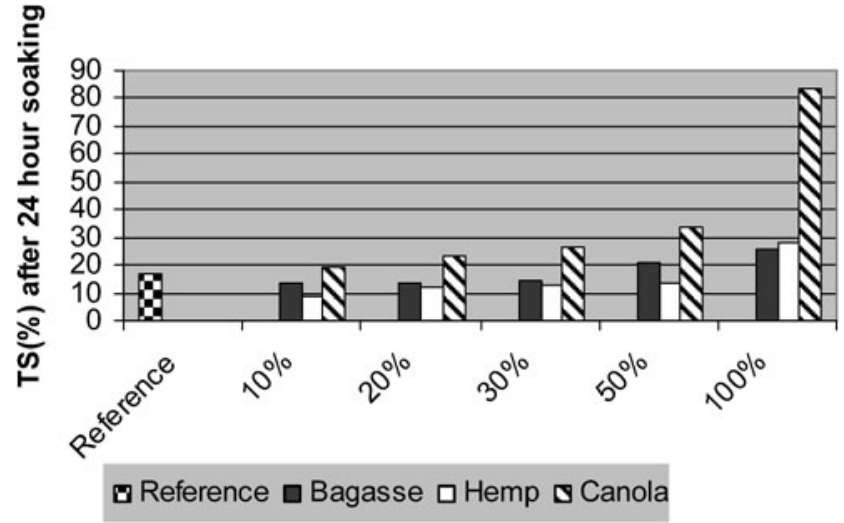

Fig. 4 Comparison of thickness swelling of particle boards, containing bagasse, hemp and canola, each in mixture with wood after 24 hour soaking

Abb. 4 Vergleich der Dickenquellung der Spanplatten jeweils mit Bagasse, Hanf und Raps in Mischung mit Holz in der Mittelschicht

ferent mixtures with wood chips indicate good mechanicaltechnological properties. The particle boards made with hemp and bagasse in mixtures of up to $50 \%$ fulfill the 
Fig. 5 Comparison of water absorption of particle boards, containing bagasse, hemp and canola, each in mixture with wood and references after 24 hour soaking

Abb. 5 Vergleich der

Wasseraufnahme der

Spanplatten jeweils mit

Bagasse, Hanf und Raps in

Mischung mit Holzspänen und

Referenzen nach 24-stündiger Quellung

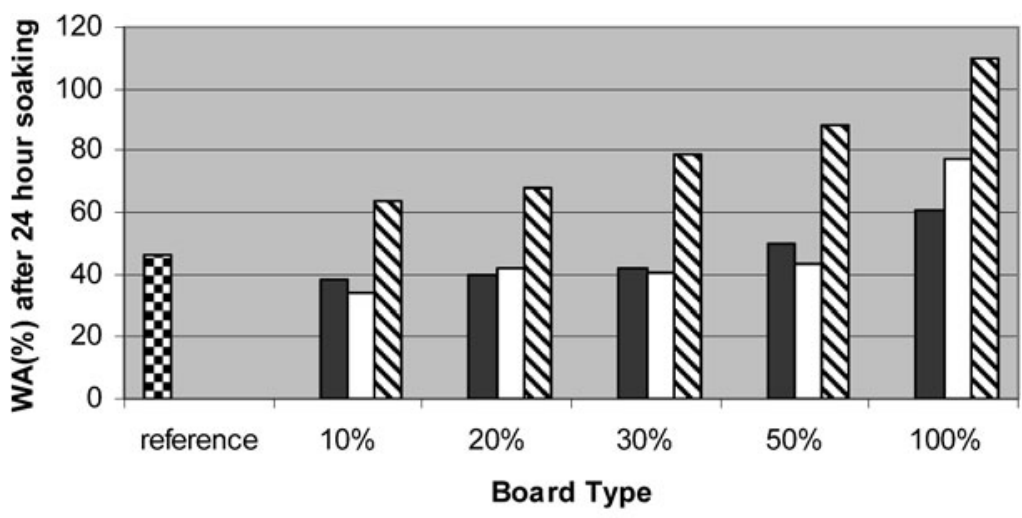

reference $\square$ Bagasse $\square$ Hemp $₫$ Canola requirements of EN 312-2 (2003). In the case of hemp sheaves, even the use of $100 \%$ is possible. The mechanicaltechnological properties of particle boards produced with canola chips in mixtures with wood chips did not meet all specifications of EN 312-2 (2003).

The additional measured water absorption and thickness swelling reveal that using hemp and bagasse of up to 50\% leads to similar results in comparison to the references. In the presence of canola the TS and WA are poor.

The achieved results of particle boards containing canola show that further investigations for better mechanicaltechnological properties are necessary. In the same case also the usage of bagasse in higher amounts for the production of particle boards has to be improved.

The main reason for these disadvantages could be the inhomogeneous structure of the milled and sized bagasse and canola chips. Therefore, for future works the use of residues of annual plants should be adapted to the process of producing particle boards.

Open Access This article is distributed under the terms of the Creative Commons Attribution Noncommercial License which permits any noncommercial use, distribution, and reproduction in any medium, provided the original author(s) and source are credited.

\section{References}

Ashori A (2006) Nonwood fiber-a potential source of row material in paper making. Polym-Plast Technol Eng 10:1133-1136

Banuelos GS, Bryla DR, Cook CG (2002) Vegetative production of Kenaf and Canola under irrigation in central California. Ind Crops Prod 15:237-245

Cescutti G, Müssig J (2005) Hanf in technischen Anwendungen: Gegenwart und Zukunft. Vortrag auf dem 10. NRW-Hanftag 2005 in Bad Sassendorf/Ostinghausen
Chen Y, Negulescu I (2002) Producing nonwoven materials from sugarcane. Louisiana Agric 45(4)

Chen JY, Chiparus O, Sun L, Negulescu II, Kuttruff J, Yachmenev VG (2003) Comparative study on Kenaf nonwoven for automotive headliner. In: The international Kenaf symposium, Beijing, China, 19-21 August 2003

COST Action E20 (2003) Wood material science research program. Wood fibre wall structure, 4-6.9. 2003

EN 312-2 (2003) European norm particle boards, part II: specifications-requirements for general purpose boards for use in dry conditions

EPF (2006) EU research framework programs; cost development of particle board industry in Europe

Karus M (2005) Europäische Hanfwirtschaft 2001 bis 2004: Anbau, Rohstoffe, Produkte und Trends. Februar 2005

Kharazipour A (2005) Holz als Werkstoff. In: Jahrbuch Nachwachsende Rohstoffe, 2004/2005. Herausgeber: CARMEN eV

Lloyd E (1996) Hemp in biocomposites, biocomposites solutions. PO box 2928, Blain, WA 98231-2928

Mueller DH, Krobjilowski A, Muessig J (2001) Molded fiberreinforced parts-special properties and influencing parameters. In: Proceedings of the 2001 beltwide cotton, conferences, Anaheim, CA, 9-13 January 2001

Ohlhauser G (2005) Beschichtete Hanfspanplatte - Cannabis Excellent. Entstehung und Marktpotential der ökologischen Leichbauplatten. PR-Nr 40175-0134-05/2005. Vortrag auf der Interzum in Köln, 29.04.-03.05.2005

Osburn LJ (1994) Hemp plywood becomes a reality. North Coast XPress, p 9, February-March 1994

Rowell RM, Keany FM (1991) Fiberboards made from acetylated bagasse fiber. Wood Fiber SciAugust 19-21, 2003 23(1):15-22

Rousu P, Anttila J (2002) Sustainable pulp production from agricultural waste. Resour Conserv Recycl 25:85-103

Schöpper C, Kharazipour A, Bohn C (2009) Production of innovative hemp based three-layered particle boards with reduced raw densities and low formaldehyde emissions. Int J Mater Prod Technol 36(1-4):358-371

Voß H, Kharazipour A (2010) Properties of light particle boards manufactured using abies grandis (grand fir). Forst Holz, 65. Jahrgang 2010(1):26-30 